\title{
TBLT Perspectives on Teaching from an EFL Textbook at a Vietnam University
}

\author{
Hao Dao \\ Victoria University of Wellington \\ Jonathan Newton \\ Victoria University of Wellington
}

\begin{abstract}
This study investigated the relationship between the affordances for task-based teaching in a textbook and teachers' awareness of and uptake of these affordances. Specifically, it compared and evaluated the communicativeness and task-likeness of activities in the textbook, New Cutting Edge, Elementary (Cunningham \& Moore, 2005) and then contrasted these findings with classroom observation data on the way the activities were implemented by three Vietnamese English as a Foreign Language (EFL) teachers at a Vietnamese university. Interviews with the teachers provided further data on their implementation decisions. The analysis and evaluation of the textbook activities and how they were implemented adopted two coding frameworks, one for evaluating communicativeness (Littlewood, 2004) and the other for evaluating task-likeness (Ellis, 2018). The analysis of communicativeness revealed that while the textbook has a high proportion of activities with low communicative value, the task analysis showed that many of these activities are, in fact, either tasks or task-like. However, form-focused activities typically precede the tasks, which compromises the alignment of the textbook with TBLT. Data from classroom observations of three 90-minute lessons taught by each teacher showed that the teachers consistently reduced the communicativeness and task-likeness of the textbook activities, and replaced them with teacher-centered, explicit grammar explanation and drill practice. Stimulated recall interviews and follow-up semi-structured interviews revealed the teachers' rationales for their practice, including their concern about the unsuitability of tasks for low proficiency students, exam pressure and time constraints, and their lack of awareness of the nature of language learning tasks.
\end{abstract}

\section{Résumé}

Cette étude a examiné la relation entre les outils pour l'enseignement par tâche présents dans un manuel et la perception des enseignants par rapport à ces outils et à leur adoption. Plus précisément, nous avons comparé et évalué le caractère communicatif et actionnel des activités présentes dans le manuel New Cutting Edge, Elementary (Cunningham et Moore, 2005). Ensuite, ces résultats ont été contrastés avec les données d'observation en classe sur la façon dont ces activités ont été réalisées par trois enseignants vietnamiens d'anglais langue étrangère (EFL) dans une université vietnamienne. Des entrevues avec les enseignants ont fourni des données complémentaires sur leurs décisions et pratiques. L'analyse et l'évaluation des activités des manuels et de la façon dont elles ont été implémentées ont adopté deux cadres de codage, l'un pour évaluer leur trait communicatif (Littlewood, 2004) et l'autre pour l'évaluation de leur caractère actionnel (Ellis, 2018). L'analyse du trait 
communicatif a révélé que le manuel contient une forte proportion d'activités ayant une faible valeur communicative, par contre l'analyse des tâches a montré qu'une quantité significative de ces activités sont, en fait, soit des tâches à proprement dire, soit des activités similaires à des tâches. Toutefois, dans ce livre, les activités axées sur la forme précèdent généralement les tâches, ce qui compromet l'alignement du manuel avec l'approche actionnelle. Les données des observations en classe de trois leçons de 90 minutes enseignées par chaque enseignant ont montré qu'elles éliminaient constamment les traits communicatifs et actionnels des activités du manuel et les remplaçaient par des explications grammaticales explicites et des pratiques d'entrainement centrées sur l'enseignant. Les entrevues de rappel stimulées et les entrevues de suivi semi-structurées ont révélé les motifs de ces pratiques de la part des enseignants, y compris leur préoccupation au sujet de l'inadéquation des tâches pour les élèves moins compétents, de la pression des examens et des contraintes de temps, de même que leur manque de sensibilisation à la nature des tâches dans l'apprentissage des langues.

\section{TBLT Perspectives on Teaching from an EFL Textbook at a Vietnam University}

The influence of task-based language teaching (TBLT) is increasingly seen in second/foreign language curricula (Thomas \& Reinders, 2015). Consequently, many teachers, especially those in many Asian-Pacific countries such as Hongkong, China, and Vietnam, are expected to adopt communicative language teaching (CLT) and TBLT (Butler, 2011; 2017; Littlewood, 2015; Thomas \& Reinders, 2015). In Vietnam, for example, the government has sought to shift from traditional form-based, teacherdominated instruction to more student-centered, communicative instruction. As the National Foreign Languages (NFL) 2008 - 2025 Project states, "a learner-centered, communicative task-based approach must be a priority" (MoET, 2008b, p. 14). This has led to a shift in university EFL programs towards textbooks that focus on communicative and task-based learning. However, the adoption of TBLT in this region has been constrained by factors such as traditional examinations, insufficient support and training for teachers, and a lack of appropriate resources (Carless, 2003; Deng \& Carless, 2009). The purpose of this research is to investigate both the affordances for communicative and task-based teaching in a textbook used at a Vietnamese university and how teachers interpreted and implemented said textbook.

\section{Literature Review}

\section{Research on Teachers Using Tasks}

A growing body of research investigates how teachers interpret and teach with tasks. Studies in which teachers design and use their own tasks have generally shown positive outcomes from a shift to task-based teaching (McDonough \& Chaikitmongol, 2007; Van den Branden, 2016; Van den Branden et al., 2007; Zhu, 2020; Zhu \& Shu, 2017). For example, Zhu reports on an action research project at a Chinese primary school in which a teacher and a researcher worked together to design, implement and evaluate task-based lessons. A valuable aspect of their study was the way it modelled a systematic,

multidimensional approach to evaluating the effectiveness of task-based teaching, one that 
included learning-based, student-based, response-based, and community-based evaluation. The study shows that when teachers are responsible for task development, they are more likely to take ownership and gain a deeper understanding of TBLT (Vandommele et al., 2018).

But research also shows that teachers often have difficulty in understanding and designing tasks (East, 2012, 2017; Erlam, 2016; Farias \& D’Elly, 2020; Oliver \& Bogachenko, 2018). Erlam reported that tasks designed by foreign language teachers in New Zealand schools after learning about TBLT rarely met all of the four task criteria proposed by Ellis and Shintani (2014, p. 135), i.e., a primary focus on meaning, some kind of gap, learners' relying on their own resources, and a communicative outcome. In particular, teachers were confused about the second criteria, thus, the "gap" that they typically included was a gap in language knowledge rather than a communicative gap. The teachers also had difficulty with the third criteria and so typically conducted explicit teaching of grammar structures and vocabulary prior to the task. In a study investigating the use of tasks by teachers in a Brazilian elementary school, Farias and D'Elly (2020) found that the teachers had difficulty in selecting and adapting tasks that were relevant and at the appropriate level for their young learners.

One option for addressing these problems is through adopting textbooks that draw, to a greater or lesser extent, on principles of TBLT. Thus, official textbooks written incountry to cater to local elementary and high schools in Asian countries such as Vietnam (Newton \& Bui, 2017; Tran, 2015), China (Hu, 2013), Hong Kong (Chan, 2019), have increasingly incorporated features of task-based teaching. Similarly, commercially produced textbooks have widely adopted versions of CLT, and to a lesser extent, TBLT. As early as 2004 Littlewood (2004) claimed that "publishers almost everywhere are describing their textbooks as task-based" (p. 319), although Long (2016) argues that "offthe-shelf commercial task-based materials" are not compatible with his strong version of TBLT (p.6).

However, research on task-based reforms, which typically involve introducing new textbooks, indicates that teachers often resist these changes (e.g., Zhang \& Luo, 2018; Carless, 2007, 2009, 2013; Lai, 2015). For example, Carless (2013) found that despite taskbased teaching being mandated in the Hong Kong secondary school curriculum, teachers consistently defaulted to a Presentation-Practice-Production (PPP) approach (also referred to as task-supported language teaching by Ellis, 2018) when teaching with the textbook. Similarly, Lai (2015) reported that Chinese primary school teachers often avoided the tasks found in their textbooks and replaced them with grammar-based instruction. Both Deng and Carless (2009) and Chen and Wright (2017) employed Littlewood's (2004) continuum of the communicativeness of classroom activities to evaluate the communicativeness of the lessons taught by the Chinese teachers. Both studies report that the teachers often implemented non-communicative, form-focused activities rather than meaning-focused tasks and, when they did use tasks, they were frequently used as add-on activities at the end of the lessons to practice linguistic structures.

Putting these findings together, we see a predictable pattern of more successful uptake of TBLT when teachers are responsible for designing and adapting tasks for their own classrooms, and poorer uptake of task-based teaching when it is introduced in the mandated textbook as part of a top-down curriculum initiative (Newton, 2021). A number of factors can account for this pattern. First, teachers' resistance to TBLT reflects the 
influence of their entrenched beliefs and practices established through their apprenticeship of observation (Lortie \& Clement, 1975; Borg, 2004). Second, top-down attempts to adopt TBLT have been shown to give insufficient attention to teacher training and professional development including teacher knowledge, procedural awareness, disposition, and teacher identity (Kiely \& Askham, 2012). In addition, factors like large classes, mixed-ability students, limited classroom time, loyalty to traditional forms-focused teaching methods, and high-stake exams have been shown to hinder the implementation of task-based teaching (Adams \& Newton, 2009; Butler, 2011, 2015; Zheng \& Borg, 2014). These issues are all currently in focus in EFL in Vietnam, where government mandated curriculum change over the past ten years has explicitly drawn on principles of TBLT and yet has struggled to achieve its intended goals.

\section{Research on the Implementation of Task-Based teaching in Vietnam}

In Vietnam, the NFL project (2008-2015) seeks to shift foreign language education from traditional form-based and teacher-dominated instruction to more student-centered, communicative instruction, with the goal of enabling students to use a foreign language to communicate confidently (MoET, 2008b). In line with this policy, textbooks that instantiate some form of task-based teaching have been officially mandated for elementary schools and high schools and encouraged in the university sector. These textbooks have produced mixed results. On the one hand, several studies show evidence of successful implementation of tasks. For example, Newton \& Bui (2017) found that, while the nine teachers in their study strictly adhered to the PPP structure of the textbook, most of them often went beyond the textbook and fostered a more communicative approach to the lessons by adding communicative games and activities in the Presentation and Production stages of the lessons. In a study based in a high school, Nguyen, Newton, and Crabbe (2018) reported that the EFL teachers consistently adapted or replaced the textbook tasks with open, input-dependent, divergent and "real" tasks to promote students' engagement. Other studies, though, have shown that teachers failed to use tasks in their classrooms. For instance, the high school teachers observed in studies by Nguyen, Le, and Barnard (2015) and Tran (2015) consistently selected vocabulary-based and form-focused activities from the textbook for their lessons and avoided the communicative activities that were also provided. Moreover, they sequenced their lessons according to the conventional PPP teaching model.

At the tertiary level, there are no common mandated textbooks used for all universities, so each EFL program chooses its own materials. Even with this freedom and the adoption of more communicative textbooks, traditional form-focused instruction is common. For example, Le and Barnard (2009) and Nguyen and Franken (2010) found that most of their teacher participants spent a large portion of their lessons explicitly teaching vocabulary and grammar, and frequently delayed communicative activities until their students were familiar with the language content of the lesson. Similarly, Nguyen et al. (2018) found that the three university EFL teachers that the study focused on consistently followed the PPP approach and taught grammar structures. The current study seeks to investigate in more detail the relationships between a textbook, the way it is implemented, and teachers' perspectives on their implementation decisions. 


\section{Methodology}

\section{Research Context}

The research site is an educational centre at a university in the North of Vietnam. This centre provides ELICOS (English language intensive courses for overseas students) training for students in transitional bachelor's programs in Business Management, Tourism Management, and Accounting. These programs are jointly taught with universities in Austria, Australia and the UK. Prior to the beginning of their bachelor studies, all students are required to join the ELICOS program, which includes 3 courses: (1) ELICOS 1, a 14week course using the textbook New Cutting Edge, Elementary; (2) ELICOS 2, a 14-week course using the textbook New Cutting Edge, Intermediate; and (3) ELICOS 3, a 23-week course of intensive IELTS training and ESP (English for Specific Purposes). At the end of each course, the students are assessed on the four skills using communicative, task-like tests, including some that are designed to approximate the IELTS test and that relate to the topics in the textbook. This study was conducted during ELICOS 1.

\section{The Textbook}

In response to the call for communicative language teaching and task-based approach from the Vietnamese Government, the textbook series New Cutting Edge was chosen by the centre's Board of Directors and has been in use in the centre since 2015 to replace the old textbook series New English File. In the current study, New Cutting Edge, Elementary was chosen for use in ELICOS 1. When using this textbook, the teachers can adapt it and decide on what needs to be covered in class and what can be assigned for selfstudy or homework as long as they can complete modules on schedule.

The textbook contains 15 modules based on various topics such as eating and drinking, buying and selling, and street life. Each module contains approximately 40 activities in five main sections: Vocabulary, Language Focus, Listening, Reading, Task, and Further Skills. All modules end with a section called Study-Practise-Remember, which is designed to cover the main lexico-grammatical content in the module. The textbook writers describe the textbook as giving "special emphasis on communication" and integrating "the elements of a task-based approach in the overall methodology" (Cunningham et al., 2005, p. 5). The results of our analysis of the textbook below provide further details of its content and of whether these claims are justified.

\section{Teacher and Student Participants}

Teacher participants were chosen using convenience sampling from $15 \mathrm{EFL}$ teachers at the university language centre. Three teachers volunteered to participate in the study. They were given the pseudonyms Huong, Lan, and Minh. All were females, in their early 30s, had completed an MA in TESOL, and had between 5-9 years of teaching experience. Their freshman classes ( 23 to 25 students each) also participated. The students had been allocated to classes on the basis of their majors: Business Management, Tourism Management and Accounting. Most of them were assessed, prior to the programs, on an IELTS-like placement test to be at an elementary level of proficiency, with a small number 
at the pre-intermediate level.

\section{Research Questions}

The study sought to investigate how the participating teachers interpreted and implemented the textbook. It addresses four research questions (RQs):

RQ 1. How communicative and task-like are the activities in the textbook?

RQ 2. When teaching from the textbook, in what ways do the teachers' practices align with or diverge from the textbook activities?

RQ 3. What reasons do the teachers give for their implementation decisions?

RQ 4. What are the teachers' stated beliefs about and knowledge of TBLT?

\section{Data Collection}

\section{Classroom Observation}

The study adopted naturalistic observation in normally scheduled lessons. This enabled data collection without interrupting the natural processes of teaching and learning (Borg, 2013). Twenty lessons covering modules 4-6 of the textbook were observed over a period of four and a half weeks, as shown in Table 1. For various logistical reasons, it was only possible to obtain a complete set of observations of all three lessons in a module taught by all three teachers for Module 6 and so the classroom observation data reported in this paper is from this module.

\section{Table 1}

Lesson Observations Scheme

\begin{tabular}{|c|c|c|c|c|c|c|c|c|c|}
\hline & \multicolumn{3}{|c|}{ Module 4} & \multicolumn{3}{|c|}{ Module 5} & \multicolumn{3}{|c|}{ Module 6} \\
\hline & \multicolumn{2}{|c|}{ Week 1} & \multicolumn{2}{|c|}{ Week 2} & \multicolumn{2}{|c|}{ Week 3} & \multicolumn{2}{|c|}{ Week 4} & \multirow{2}{*}{$\frac{\text { Week } 5}{3}$} \\
\hline Lesson & 1 & 2 & 3 & 1 & 2 & 3 & 1 & 2 & \\
\hline Lan & $\checkmark$ & $\sqrt{ }$ & & $\checkmark$ & & $\checkmark$ & $\sqrt{ }$ & $\checkmark$ & $\sqrt{ }$ \\
\hline Huong & $\checkmark$ & & $\checkmark$ & $\sqrt{ }$ & $\sqrt{ }$ & & $\sqrt{ }$ & $\checkmark$ & $\checkmark$ \\
\hline Minh & & $\sqrt{ }$ & $\checkmark$ & & & $\checkmark$ & $\sqrt{ }$ & $\checkmark$ & $\checkmark$ \\
\hline
\end{tabular}

\section{Interviews}

Each teacher took part in a stimulated recall interview (SRI) after each lesson and, at the end of data collection, a semi-structured interview (SSI). The Vietnamese language was used in all interviews. SRIs were conducted within one day of the relevant lesson and were 35 to 40 minutes long. During the SRIs, the researcher played an audio-visual recording of selected sections of the lesson and, at predetermined points, paused the audiovisual recording and asked the teachers to recall what was happening and why. The SSIs 
were 30-minute semi-structured interviews which took place three to five days after Module 6 had been taught. They were designed to obtain additional information about the teachers' beliefs concerning TBLT and to triangulate information from the SRIs and classroom observations.

\section{Data analysis}

\section{Analysis of Textbook Activities}

To address RQ1, the activities in three modules in the textbook (Module 4, 6, and 8 ) were selected for analysis. Since the analysis of all three modules revealed nearly identical data in each module, only the analysis of Module 6 is reported. This is also the module for which classroom observation data is reported. To analyze for communicativeness, all activities were coded using Littlewood's (2004) continuum of communicativeness (See Figure 1). While this framework has limitations, which are discussed in the Findings section, it provided useful criteria for coding the communicativeness of the textbook activities.

Figure 1

Continuum of Communicativeness of Activities (Littlewood, 2004, p.322)

\begin{tabular}{|c|c|c|c|c|}
\hline Focus on form & & $\leftarrow$ & $\rightarrow$ & $\begin{array}{l}\text { Focus on } \\
\text { meaning }\end{array}$ \\
\hline $\begin{array}{l}\text { 1. Non- } \\
\text { communicative } \\
\text { learning }\end{array}$ & $\begin{array}{l}\text { 2. Pre- } \\
\text { communicative } \\
\text { language } \\
\text { practice }\end{array}$ & $\begin{array}{l}\text { 3. Communi- } \\
\text { cative language } \\
\text { practice }\end{array}$ & $\begin{array}{l}\text { 4. Structure } \\
\text { communication }\end{array}$ & $\begin{array}{l}\text { 5. Authentic } \\
\text { communication }\end{array}$ \\
\hline $\begin{array}{l}\text { Focus on the } \\
\text { structures of } \\
\text { language, how they } \\
\text { are formed and } \\
\text { what they mean }\end{array}$ & $\begin{array}{l}\text { Practice language } \\
\text { with some } \\
\text { attention to } \\
\text { meaning but not } \\
\text { communicating } \\
\text { new messages to } \\
\text { others }\end{array}$ & $\begin{array}{l}\text { Practice pre-taught } \\
\text { language in a } \\
\text { context where it } \\
\text { communicates new } \\
\text { information }\end{array}$ & $\begin{array}{l}\text { Use language to } \\
\text { communicate in } \\
\text { situations that } \\
\text { elicit pre-learnt } \\
\text { language, but } \\
\text { with some } \\
\text { unpredictability }\end{array}$ & $\begin{array}{l}\text { Use language to } \\
\text { communicate in } \\
\text { situations where } \\
\text { the meanings are } \\
\text { unpredictable }\end{array}$ \\
\hline
\end{tabular}

Note. This table is adapted from "The task-based approach: some questions and suggestions" by Littlewood (2004, p. 322).

To provide a clearer analysis, the activities in categories 1 and 2 are treated as low communicative value activities (LCV) while those in categories 3-5 are treated as high communicative value (HCV).

To evaluate the task-likeness of the textbook activities, all were coded for the presence or absence of the four task criteria proposed by Ellis $(2018$, p. 12), which are presented in Table 2. In the past, researchers have reported difficulties coding activities with earlier versions of these criteria (Shintani \& Ellis, 2014; Erlam, 2016; Butler et al., 2018). The revised set of task features in Ellis (2018) are more elaborated, which makes them clearer and more workable for coding purposes. In presenting this revised list, Ellis makes a crucial distinction between "task-as-workplan" as an educational unit of planning (task-as-workplan) and "task" as the activity that learners engage in (task-in-process). The current study treats the textbook activities and the teachers' presentation of them in the 
classroom as manifestations of the task-as-workplan. One adaptation for the purpose of coding in the current study was to treat the nature of each activity as distinct from the sequencing of activities. For this reason, the first sentence in criterion 3 (see Table 2), which addresses the overall sequencing of activities rather than the intrinsic nature of each activity was not applied in the activity coding process. The sequencing of activities is central to TBLT, so this issue is discussed elsewhere in this paper in relation to the way language-focused activities precede the main task in each module in this textbook.

Table 2

Coding Ellis (2018)'s Framework for Task-as-Workplan

\begin{tabular}{l|l}
\hline \multicolumn{1}{c}{ Criteria } & \multicolumn{1}{c}{ Elaboration } \\
\hline $\begin{array}{l}\text { 1. The primary } \\
\text { focus is on meaning }\end{array}$ & $\begin{array}{l}\text { The workplan is intended to ensure that learners are primarily concerned with } \\
\text { comprehending or/and producing messages for a communicative purpose. }\end{array}$ \\
$\begin{array}{l}\text { kind of gap } \\
\text { 3. Learners rely } \\
\text { mainly on their own } \\
\text { resources }\end{array}$ & $\begin{array}{l}\text { The workplan is designed in such a way as to incorporate a gap that will need } \\
\text { to be closed when the task is performed. The gap creates a need to convey } \\
\text { information, to reason or to express an opinion. }\end{array}$ \\
$\begin{array}{l}\text { The workplan does not include any presentation of the language needed to } \\
\text { perform the task, although it may supply input that can be "borrowed" during } \\
\text { the performance of the task. Learners need to draw on their existing linguistic } \\
\text { resources (potentially both L1 and L2) and their non-linguistic resources (e.g., } \\
\text { gesture; facial expressions) for comprehension or/and production. }\end{array}$ \\
$\begin{array}{l}\text { 4. There is a clearly } \\
\text { defined } \\
\text { communicative } \\
\text { outcome }\end{array}$ & $\begin{array}{l}\text { The workplan specifies the communicative outcome of the task. Thus, task } \\
\text { accomplishment is to be assessed not in terms of whether learners use } \\
\text { language correctly but in terms of whether the communicative outcome is } \\
\text { achieved. }\end{array}$ \\
\hline
\end{tabular}

Activities that fulfilled all four criteria were coded as tasks. Those that fulfilled two to three of the criteria were coded as task-like, and those that only fulfilled one or none of the criteria were coded as non-tasks.

\section{Analysis of Teachers' Teaching Practices}

The coding of how the teachers' practices aligned with or diverged from the textbook activities was entered into a separate table for each teacher as seen in Table 3 , which is a small sample of the analysis of Lan's lessons. The design of the table allowed for an analysis of each textbook activity and what each teacher did with it. Coding the observational data involved the following steps:

Step 1. Construct initial descriptions of observed activities. The recording of each lesson was viewed several times so as to produce brief written descriptions of each activity (see column 3 in Table 3).

Step 2. Code for adherence to the textbook. The teachers' activities were coded as to whether they retained, adapted, added, or removed textbook activities (see column 5 in Table 3). These coding categories were developed by B. T. Nguyen et al. (2018).

Step 3. Code for communicativeness and task-likeness of activities. The teachers' activities were coded using Littlewood's (2004) continuum of communicativeness (see 
Figure 1). This provided information on the extent to which the teachers' practices strengthened or weakened the communicativeness of the textbook. Columns 2 and 4 in Table 3 illustrate this coding step.

Step 4. Quantify the data. The coded data from steps 1-3 were converted into numerical data to allow for comparisons between the teachers and between the textbook and the teachers, as seen in Tables 8 to 10 .

Table 3

Analysis of Lesson 1 from Module 6: Lan

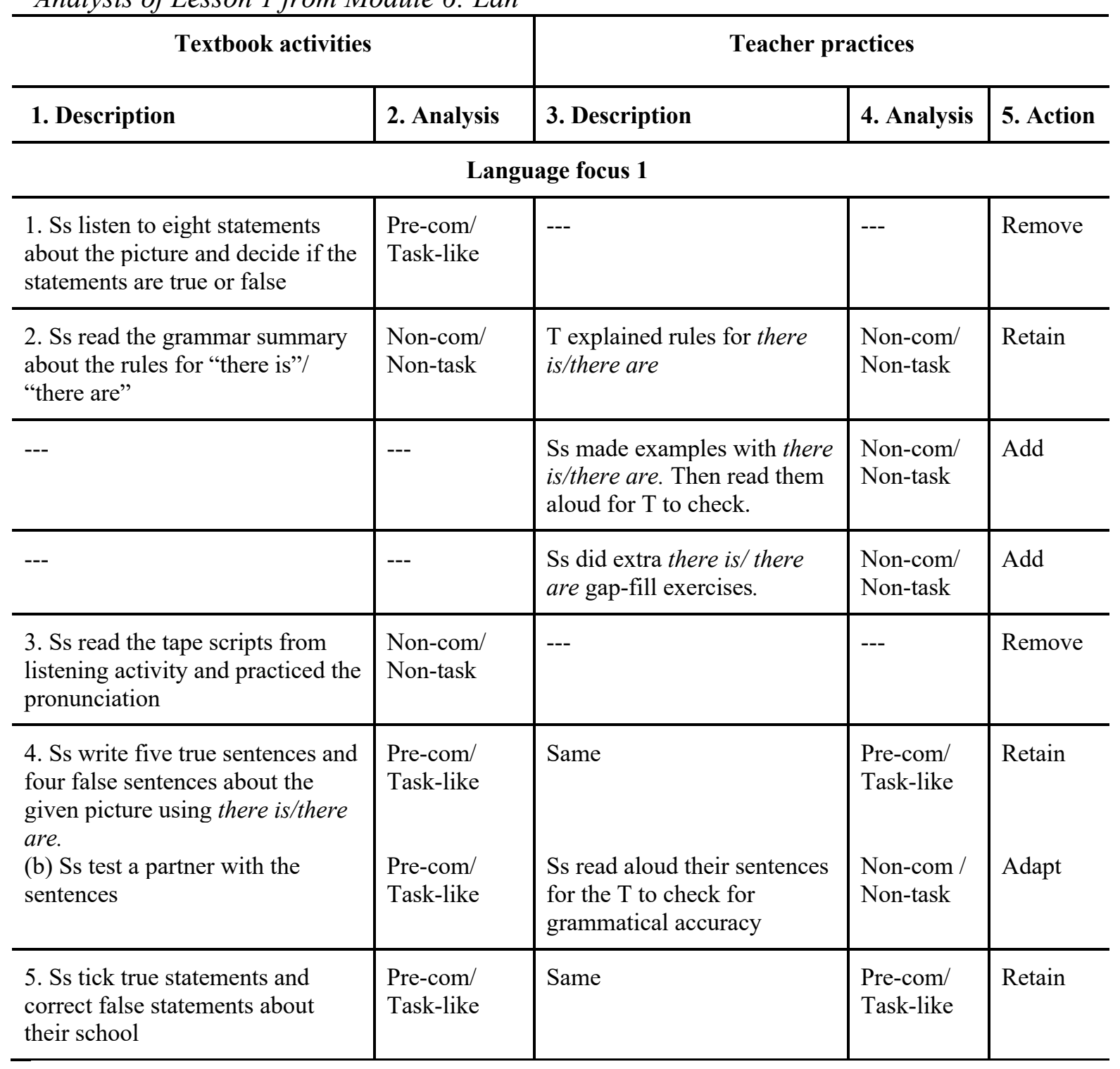

\section{Inter-rater Reliability}

The first author and another trained rater independently coded 45 activities $(30 \%$ of the data). Inter-coder reliability scores were calculated for coding the communicativeness 
and task-likeness of the activities using both percentage agreement and Cohen's kappa coefficient $(\kappa)$. The percentage agreement when coding with Littlewood's (2004) framework was $91 \%$ with $\kappa$ being 0.8 . The percentage agreement when coding with Ellis's (2018) framework was 93 with $\kappa$ being 0.84 . These results show satisfactory reliability. Consensus on all remaining items was achieved through discussion between the raters.

\section{Analysis of Interviews}

The recorded interviews (including nine SRIs and three SSIs) were transcribed and the accuracy of the transcriptions was cross-checked against the original recording before being sent to the three teachers for member-checking. In the SRI data, key content words and phrases such as "weak", "passive", "lazy", which the teachers used to describe their students, were first coded on each interview transcript. These codes were then collated into thematic categories which captured the rationales of each teacher. This process identified similarities and differences across the teachers' explanations for their implementation decisions. Table 4 illustrates how a part of Lan's SRI data was analyzed.

Table 4

Analysis of SRI Data from Lan

\begin{tabular}{l|l|l|l}
\hline Excerpts & Codes & Categories & Themes \\
\hline $\begin{array}{l}\text { Học sinh các em ấy yếu lắm, không biết gì nhiều từ } \\
\text { vựng ngữ pháp đâu (The students are weak, they did } \\
\text { not know much vocabulary and grammar) }\end{array}$ & Weak & $\begin{array}{l}\text { Students' low } \\
\text { English } \\
\text { proficiency }\end{array}$ & $\begin{array}{l}\text { Student } \\
\text { characteristics }\end{array}$ \\
\begin{tabular}{ll|l} 
Học sinh lớp tôi toàn đợi tôi chỉ đến tận nơi mới \\
làm, bị động lắm (The students in my class were \\
quite passive, they often waited until I provided \\
them with the necessary language then they did the \\
activity)
\end{tabular} & Passive & $\begin{array}{l}\text { Students' } \\
\text { affective states }\end{array}$ & \\
$\begin{array}{ll}\text { Họ rất lười, thường ngủ gật trong lớp (They were } \\
\text { quite lazy and often dozed off during the lessons) }\end{array}$ & Lazy & & \\
\hline
\end{tabular}

For the semi-structured interviews, initial coding involved identifying repeated words/phrases relevant to the research questions. These codes were then collated to identify patterns and themes for each teacher and across the three teachers.

\section{Findings and Discussion}

Results are reported for the four research questions that guided this study.

\section{Findings (RQ1): Textbook Analysis}

This section reports on findings from the analysis of 39 activities from Module 6 in the textbook and addresses RQ1, which concerns the communicativeness and task-likeness features of the textbook activities. 
Table 5 presents the analysis of the communicativeness of the 39 activities in Module 6 . The analysis shows that $24(61 \%)$ of the activities have low communicative value (LCV), and 15 (39\%) have high communicative value (HCV).

\section{Table 5}

The Communicativeness of Activities

\begin{tabular}{cc|ccc|c}
\hline \multicolumn{2}{l|}{ Low communicative value (LCV) } & \multicolumn{2}{c|}{ High communicative value (HCV) } & Total \\
\hline Non-com & Pre-com & Com & Struc-com & Auth-com & \\
9 & 15 & 9 & 1 & 5 & \\
\hline \multicolumn{2}{c|}{ Total } & $24(61 \%)$ & & $15(39 \%)$ & $39(100 \%)$ \\
\hline
\end{tabular}

This analysis suggests that the textbook might be out of step with the claim it makes that it "gives special emphasis on communication" and "integrates the elements of task-based approach in the overall methodology" (Cunningham et al., 2005, p. 5). However, further analysis of the extent to which the 39 activities displayed Ellis's (2018) four criterial features of tasks, as presented in Tables 6 and 7, gives greater credence to the writers' claims. Table 6 presents the analysis of the $15 \mathrm{HCV}$ activities. Eight of these activities met all four task criteria and the remaining seven met three criteria except Criterion 4, a communicative outcome. 
Table 6

The Task-likeness of High Communicative Value Activities

\begin{tabular}{|c|c|c|c|c|c|c|}
\hline \multirow[t]{2}{*}{ Activities } & \multicolumn{4}{|c|}{ Four task criteria } & \multirow{2}{*}{$\begin{array}{l}\text { Task- } \\
\text { likeness }\end{array}$} & \multirow{2}{*}{$\begin{array}{l}\text { Commu- } \\
\text { nicative-ness }\end{array}$} \\
\hline & C1 & $\mathbf{C 2}$ & C3 & $\mathbf{C 4}$ & & \\
\hline $\begin{array}{l}\text { 1. Ss work in pairs to categorize words into countable/uncountable } \\
\text { nouns }\end{array}$ & & $\sqrt{ }$ & $\sqrt{ }$ & $\sqrt{ }$ & Task-like & Com \\
\hline 2. Ss ask and answer questions about their lifestyle & $\sqrt{ }$ & $\sqrt{ }$ & $\sqrt{ }$ & & Task-like & Com \\
\hline 3. Ss discuss the answers for the questionnaire & $\sqrt{ }$ & $\sqrt{ }$ & $\sqrt{ }$ & & Task-like & Com \\
\hline 4. Ss ask and answer questions about their favorite restaurants & $\sqrt{ }$ & $\sqrt{ }$ & $\sqrt{ }$ & & Task-like & Com \\
\hline 5. Ss ask and answer questions about their favorite foods & $\sqrt{ }$ & $\sqrt{ }$ & $\sqrt{ }$ & & Task-like & Com \\
\hline 6. Ss discuss to find foods that contain minerals, protein, calories & $\sqrt{ }$ & $\sqrt{ }$ & $\sqrt{ }$ & & Task-like & Com \\
\hline 7. Ss write about their normal meals & $\sqrt{ }$ & $\sqrt{ }$ & $\sqrt{ }$ & & Task-like & Com \\
\hline 8. Ss work in pairs to remember and list ten things Katie buys & $\sqrt{ }$ & $\sqrt{ }$ & $\sqrt{ }$ & $\sqrt{ }$ & Task & Com \\
\hline 9. Ss discuss which foods that Katie buys are healthy and unhealthy & $\sqrt{ }$ & $\sqrt{ }$ & $\sqrt{ }$ & $\sqrt{ }$ & Task & Com \\
\hline 10. Ss ask and answer to find ten differences of two pictures & $\sqrt{ }$ & $\sqrt{ }$ & $\sqrt{ }$ & $\sqrt{ }$ & Task & Com \\
\hline $\begin{array}{l}\text { 11. Ss work in pairs to match the ideas with the corresponding } \\
\text { paragraphs }\end{array}$ & $\sqrt{ }$ & $\sqrt{ }$ & $\sqrt{ }$ & $\sqrt{ }$ & Task & Com \\
\hline 12. Ss work in pairs to do role play & $\sqrt{ }$ & $\sqrt{ }$ & $\sqrt{ }$ & $\sqrt{ }$ & Task & Struc-com \\
\hline $\begin{array}{l}\text { 13. Ss talk about their breakfast and compare with people in a listening } \\
\text { text }\end{array}$ & $\sqrt{ }$ & $\sqrt{ }$ & $\sqrt{ }$ & $\sqrt{ }$ & Task & Auth-Com \\
\hline $\begin{array}{l}\text { 14. Ss guess if the given statements are true or false then compare with } \\
\text { their friends }\end{array}$ & $\sqrt{ }$ & $\sqrt{ }$ & $\sqrt{ }$ & $\sqrt{ }$ & Task & Auth-com \\
\hline 15. Ss discuss to make a list of eight healthy and eight unhealthy foods & $\sqrt{ }$ & $\sqrt{ }$ & $\sqrt{ }$ & $\sqrt{ }$ & Task & Auth-com \\
\hline
\end{tabular}

Table 7 presents the analysis of the $24 \mathrm{LCV}$ activities. Eleven of these activities did not fulfill any of the four task criteria and so can be considered to be non-tasks. However, the 13 activities coded as pre-communicative met all or some of the task criteria. Two met all the criteria and so can be considered tasks, and the remaining 11 met at least two of the criteria, and in most cases, three, and so can be considered to be task-like in some way. 
Table 7

The Task-Likeness of Low Communicative Value Activities

Activities$$
\begin{array}{llll}
\text { C } & \mathbf{C} & \mathbf{C} & \mathrm{C}
\end{array}
$$$$
\begin{array}{llll}
1 & 2 & 3 & 4
\end{array}
$$

Four task criteria Tasklikeness
1. Ss read grammar summary about the rules for there is/there are

2. Ss complete sentences with some/any

3. Ss read the tapescript of listening text and practice the pronunciation

4. Ss read grammar summary about the rules for some/any

5. Ss practice pronunciation about sentence stress

6. Ss read grammar summary about the rules for How many/ How much

7. Ss practice pronunciation about intonation

8. Ss do gap-fill exercise with how much/how many

9. Ss do gap-fill exercise with some/any

10. Ss match the foods with the pictures

11. Ss match the words with the things in the given picture

12. Ss tick true statements and correct false statements about their school

13. Ss look at the photos and decide if the sentences are true or false

14. Ss decide if the sentences are true or false to the previous reading text

15. Ss answer questions related to the picture

16. SS complete the food and drink scrambled words

17. Ss listen to eight statements about the picture and decide if the statements are true or false

18. Ss write five true sentences and four false sentences about the given picture using there is/there are

19. Ss listen and take notes of what people have for breakfast

20. Ss listen to three conversations and answer the questions

21. Ss listen to conversations and complete the missing information

22. Ss write true sentences about their town with there is/are

23. Ss listen to someone describing picture and number things in order

24. Ss put the conversation in the correct order
Non-task Non-com

Non-task Non-com

Non-task Non-com

Non-task Non-com

Non-task Non-com

Non-task Non-com

Non-task Non-com

Non-task Non-com

Non-task Non-com

Non-Task Pre-com

Non-Task Pre-com

Task-like Pre-com

Task-like Pre-com

Task-like Pre-com

$\checkmark \sqrt{ } \sqrt{ } \quad$ Task-like Pre-com

$\checkmark \quad \checkmark \quad \checkmark$ Task-like Pre-com

$\checkmark \sqrt{ } \quad$ Task-like Pre-com

$\checkmark \sqrt{ } \quad \sqrt{ }$ Task-like Pre-com

$\sqrt{ } \sqrt{ } \quad$ Task-like Pre-com

$\checkmark \sqrt{ } \quad \sqrt{ } \quad$ Task-like $\quad$ Pre-com

$\sqrt{ } \sqrt{ } \quad$ Task-like Pre-com

$\sqrt{ } \quad \sqrt{ }$ Task-like Pre-com

$\sqrt{ } \quad \sqrt{ } \quad \sqrt{ }$ Task Pre-com

$\sqrt{ } \quad \sqrt{ } \quad \sqrt{ }$ Task $\quad$ Pre-com 
In sum, the analyzes in Tables 6 and 7 show that of the 39 activities in Module 6, 10 were tasks, 18 task-like activities, and 11 non-tasks. These figures suggest that Littlewood's communicativeness continuum undersells the task-likeness of many activities, and especially those that are input-based (Erlam \& Ellis, 2018). While it is true that inputbased activities may not require learners to produce communicative output (speaking or writing), they nevertheless often engage them in responding in task-like ways (e.g. matching or sequencing pictures, listening and labelling a diagram or map) to the message in meaning-focused reading or listening Thus, although there were more LCV activities than HCV activities (61\% compared with $39 \%$ in Module 6), most LCV activities had some features of tasks (11) or were in fact tasks (2). For example, Activity 23 in Table 7 requires students to listen to a person describing a picture and number the things mentioned in the correct order. In Littlewood's framework, this is categorized as pre-communicative language practice. However, it clearly contains all four task features: a focus on meaning, a gap, learners using their own resources and a non-linguistic outcome. Overall, our analysis confirms comments made by Ellis (2018) about New Cutting Edge that, despite the overall sequence of activities reflecting a task-supported (i.e., PPP) rather than a task-based approach, nevertheless, "it provides models which prepare learners to do tasks", and "teachers could do these without first doing the preparatory exercise- type activities" (p.269). The question of the extent to which the teachers followed or diverged from the textbook is addressed in the following section.

\section{Findings (RQ2): Teachers' Teaching Practice}

In response to RQ2, this section reports on the analysis of the three Module 6 lessons taught by each of the three teachers and the extent to which their practices aligned with or diverged from the textbook activities. The results are reported separately for each teacher.

Table 8 reports the analysis of Lan's teaching. Of the $24 \mathrm{LCV}$ activities in the textbook, Lan retained 15 (row 1), added six more (row 2), and removed five (row 3). Of the $15 \mathrm{HCV}$ activities, she retained six, removed five (row 3 ) and adapted four HCV activities by reducing their communicativeness (row 4a), and so made them into LCV (row 4b). Overall, the majority of the activities in Lan's three lessons were LCV (29 activities or $83 \%$, compared to $6 \mathrm{HCV}$ activities or $17 \%$ ). 
Table 8

Lan's Teaching of Module 6

\begin{tabular}{l|cc|ccc|c}
\hline & \multicolumn{2}{|c|}{ LCV } & HCV & \multirow{2}{*}{ Total } \\
\cline { 2 - 7 } & $\begin{array}{l}\text { Non- } \\
\text { com }\end{array}$ & $\begin{array}{c}\text { Pre- } \\
\text { Com }\end{array}$ & Com & $\begin{array}{c}\text { Struc- } \\
\text { Com }\end{array}$ & $\begin{array}{c}\text { Auth- } \\
\text { Com }\end{array}$ & \\
\hline Textbook activities & $\mathbf{9}$ & $\mathbf{1 5}$ & $\mathbf{9}$ & $\mathbf{1}$ & $\mathbf{5}$ & \multirow{2}{*}{39} \\
\hline 1. Retained & 7 & 8 & 4 & 1 & 1 & \\
2. Added & 6 & 0 & 0 & 0 & 0 & \\
3. Removed & 2 & 3 & 4 & 0 & 1 & \\
4a. Adapted & 0 & 4 & 1 & 0 & 3 & \\
4b. Adapted into this category & 7 & 1 & 0 & 0 & 0 & \\
5. Total = (1)+(2)+(4b) & 20 & 9 & 4 & 1 & 1 & 35 \\
& $(57 \%)$ & $(26 \%)$ & $(11 \%)$ & $(3 \%)$ & $(3 \%)$ & \\
\hline
\end{tabular}

Table 9 shows a similar pattern in Huong's teaching. Of the 24 LCV activities in the textbook, Huong retained 15 (row 1) and added four more (row 2). Of the $15 \mathrm{HCV}$ activities, she retained six, removed two (row 3 ) and adapted seven HCV activities by reducing their communicativeness (row 4a), and so made them into LCV (row 4b). Overall, the majority of the activities in Huong's three lessons were LCV (30 activities or $84 \%$, compared to $6 \mathrm{HCV}$ activities or $16 \%$ ).

\section{Table 9}

Huong's Teaching of Module 6

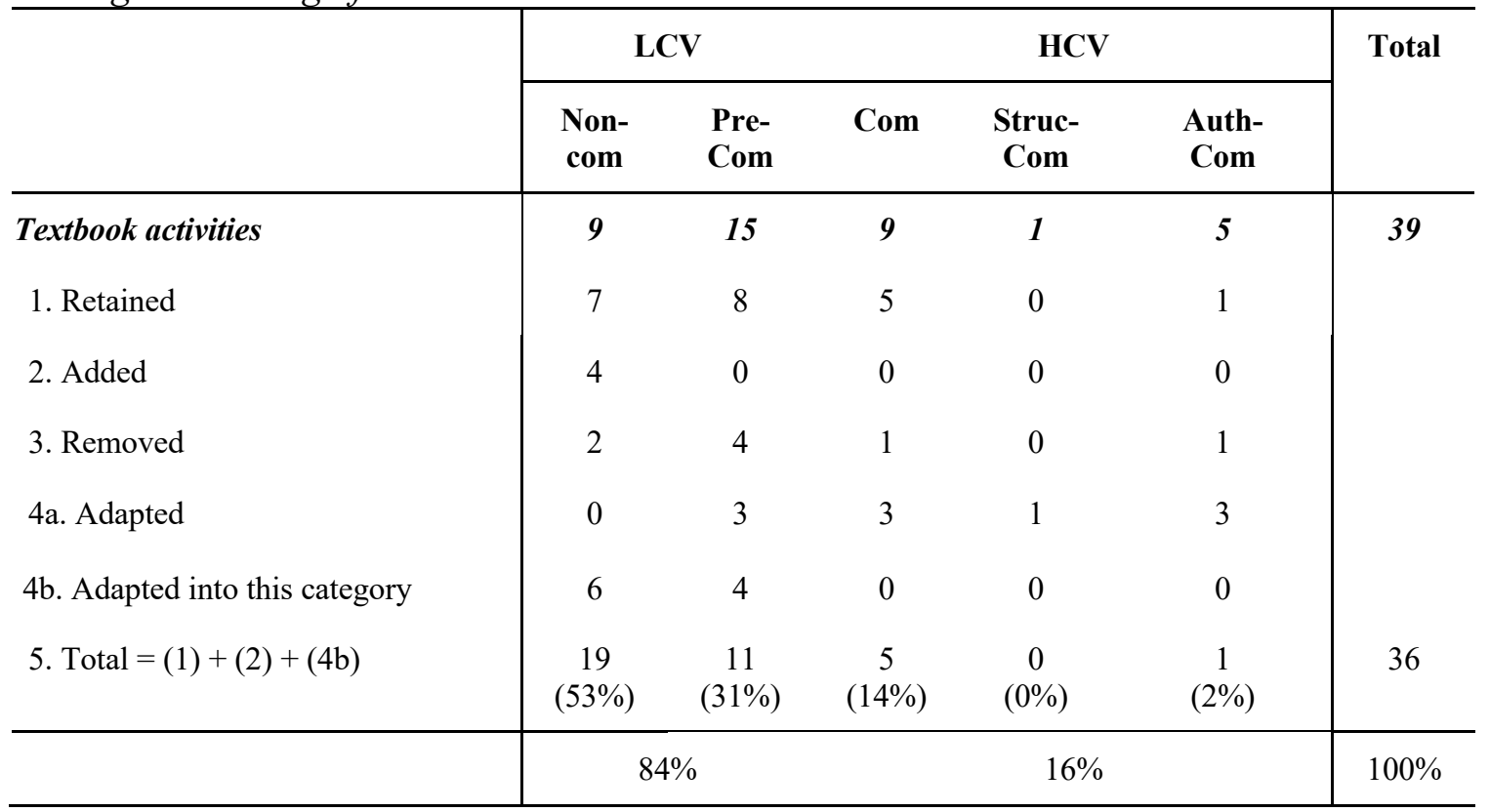


Table 10 shows a similar pattern in Minh's lessons compared with Lan and Huong. Of the 24 LCV activities in the textbook, Minh retained 6 (row 1), added three more (row 2 ), and removed three (row 3). Of the $15 \mathrm{HCV}$ activities, she retained eight, removed three (row 3 ) and adapted four HCV activities by reducing their communicativeness (row 4a), so made them into LCV (row 4b). Overall, the majority of the activities in Minh's three lessons were LCV (30 activities or $79 \%$, compared to $8 \mathrm{HCV}$ activities or $21 \%$ ).

Table 10

Minh's Teaching of Module 6

\begin{tabular}{|c|c|c|c|c|c|c|}
\hline & \multicolumn{2}{|c|}{ LCV } & \multicolumn{3}{|c|}{$\mathrm{HCV}$} & \multirow[t]{2}{*}{ Total } \\
\hline & $\begin{array}{l}\text { Non- } \\
\text { com }\end{array}$ & $\begin{array}{l}\text { Pre- } \\
\text { Com }\end{array}$ & Com & $\begin{array}{l}\text { Struc- } \\
\text { Com }\end{array}$ & $\begin{array}{l}\text { Auth- } \\
\text { Com }\end{array}$ & \\
\hline Textbook activities & 9 & 15 & 9 & 1 & 5 & 39 \\
\hline 1. Retained & 6 & 7 & 5 & 1 & 2 & \\
\hline 2. Added & 6 & 3 & 0 & 0 & 0 & \\
\hline 3. Removed & 3 & 4 & 2 & 0 & 1 & \\
\hline 4a. Adapted & 0 & 4 & 2 & 0 & 2 & \\
\hline 4b. Adapted into this category & 7 & 1 & 0 & 0 & 0 & \\
\hline \multirow[t]{2}{*}{ 5. Total $=(1)+(2)+(4 b)$} & $\begin{array}{c}19 \\
(50 \%)\end{array}$ & $\begin{array}{c}11 \\
(29 \%)\end{array}$ & $\begin{array}{c}5 \\
(14 \%)\end{array}$ & $\begin{array}{c}1 \\
(2 \%)\end{array}$ & $\begin{array}{c}2 \\
(5 \%)\end{array}$ & 38 \\
\hline & \multicolumn{2}{|c|}{$79 \%$} & \multicolumn{3}{|c|}{$21 \%$} & $100 \%$ \\
\hline
\end{tabular}

In summary, the consistent practice for all three teachers was to dramatically reduce the communicativeness and task-likeness of the textbook activities. They did this in three ways. First, they retained almost all the existing non-communicative activities and added many more. This reveals a strong preference for explicit, decontextualized, teachercentered grammar teaching. This preference reflected a "get it right from the beginning" approach in which learners are seen to involve accumulating and mastering one grammatical form after another (Lightbown \& Spada, 2006, p. 154) rather than "learning by doing", which is a fundamental feature of TBLT (Long, 2016, p.7). Second, the teachers typically reduced the communicativeness of the activities by replacing purposeful, meaningful interaction between students, as stipulated in the textbook, with teacher-fronted whole class work or individual work. Consequently, there was minimal evidence of the students exchanging information or negotiating meaning with each other or even with the teacher. Third, when communicative activities were present in the lessons, they were always preceded by explanations from the teachers of linguistic patterns and drill-type practice activities. In most cases, these activities were added by the teachers. In addition, because these activities took a lot of lesson time, there was usually insufficient time to implement the textbook tasks. These three features of the lessons are in line with findings 
from other studies in the Asian context, such as Lai (2015), Nguyen et al. (2015) and Tran (2015). In all these studies, the teachers also consistently selected activities with low communicative value and avoided tasks that were provided in the textbook. To understand the implementation decisions in the current study, the next section reports on findings from the SRIs.

\section{Findings (RQ3): Reasons for Implementation Decisions}

This section reports on findings from the nine SRIs and addresses RQ3, which concerns the reasons the teachers gave for their implementation decisions. The analysis revealed three main reasons for the teachers' implementation decisions. First, all three teachers frequently cited their students' low English proficiency and their affective states when justifying their teaching practices, as seen in the quotes from Huong and Lan.

I spent much time on teaching and practicing grammatical structures with the students because their knowledge of English is limited. (Huong, SRI1)

Now they [the students] are still at the low level so they need to focus on practicing the grammar and structures until they get used to them. When they move to a higher level, they can spend more time on using such structures in communication. Now I think if I ask them to do communicative activities, it will be very hard for them. (Lan, SRI1)

The teachers also reported that the students' attitudes and emotions influenced how they implemented the textbook. They used various adjectives such as "dependent", "inactive", "lazy", "not enthusiastic", "reluctant", and "shy" to describe the students' affective states. For example, when asked why her students were often assigned individual work instead of pair work as suggested in the textbook, Lan responded:

I saw that the students were rather reluctant and not really enthusiastic when working in pairs or in groups. I remember that I asked them to ask and answer what food they liked and disliked, but most of the pairs just asked one or two questions and then started to talk in Vietnamese, use mobile phones, or even say nothing. Therefore, I minimized the pair work time, let students do the activities on their own. (Lan, SRI1)

When asked why she spent much time explaining the meaning of the words and did translation of the reading text into Vietnamese, Minh commented:

It is likely that some of the students did not understand the listening or reading texts, or they did not know how to express their ideas, but they were too shy to ask or raise questions. Therefore, I explained everything clearly for them, I translated into Vietnamese for them to make sure that they understood the lessons. (Minh, SRI1) 
In short, the three teachers perceived that their students were not motivated enough to engage with communicative tasks and that communicative tasks were not suitable for such low proficiency students. This perception is a common misunderstanding about TBLT (Ellis, 2015, 2018a). But as Ellis (2018) argues, task-based learning is particularly beneficial for lower-proficiency students since it is well suited to helping them become fluent in using lexicalized chunks of language. Evidence from studies by Shintani (2016), Erlam and Ellis (2018), and Newton \& Bui (2017) support this claim and highlight the affordances of implementing task-based learning for low proficiency learners.

The second reason all three teachers gave for their teaching practice was examination pressure. They all believed that explicit grammar explanation and controlled practice rather than communicative activities were priorities for helping their weak students succeed in the exams.

The reason why I spent much time explaining things clearly for the students and let them practice the grammar items is that I want them to get familiar with the structures. They need to pass the exam next year. That is their ultimate goal now. I believe once they know and remember the structures or words, they can understand the texts or speak and write the sentences which are grammatically correct. (Lan, SRI1)

I don't deny the advantages of these communicative activities for the students, but I think these activities are just good for improving students' speaking skills. If the students just focus on carrying out these activities, then I think it is not really useful for them to do well in the exam. That is the reason why I skipped some textbook activities and handed out exercises for the students to practice instead. (Huong, SSI1)

Previous research in Asian contexts has also found that teachers often prioritize teaching grammar structures to prepare students for examinations, which have traditionally emphasized testing of linguistic knowledge (Adams \& Newton, 2009; Deng \& Carless, 2009; Zhang, 2015). As T. Nguyen (2013) notes, this belief reflects a Confucian ideology about education in that "knowledge should be accurately provided by the teachers and memorized by the learners so that no errors may occur when this knowledge has to be returned, such as in examinations" (p. 273). Interestingly, however, in the context of the current study, the mid-term and final term tests resemble the IELTS exam and so emphasize communicative reading, writing, speaking, and listening. As Carless (2007) argues, "it may be teacher beliefs and school practicalities rather than examinations that are a more significant barrier to task-based approaches" (p. 605).

The third impediment to implementing TBLT that all teachers identified was limited instructional hours. As Minh explained:

If I had had more time, I would have organized a group discussion in this part. [...] But I needed to teach the structures, the vocabulary, then I needed to translate the text into Vietnamese to make sure that all the students understood the content of the text $[\ldots]$ So I did not have enough time for group discussion [...] I think that since 
the time was limited, we teachers could not always do properly what we wanted to do. (Minh, SRI1)

This problem of limited classroom time is predicated on the assumption as stated by Minh that target structures must be thoroughly taught before tasks are introduced. However, as Ellis (2018, p. 112) argues, if the aim is to develop interaction competence and communicative L2 use, then this cannot be achieved by reliance on grammatical structure teaching. This argument applies to the current program where the goals are for students to pass the communicatively-oriented IELTS exams and to prepare for their major subjects through English. To gain a deeper understanding of the teachers' decision-making, the next section reports on findings from follow-up SSIs.

\section{Findings (RQ4): Teacher Perspectives on TBLT}

This section draws on SSI data to address RQ4, which concerns the teachers' knowledge and beliefs about TBLT. First, the teachers were shown the various tasks in the textbook and asked what they understood about the term "task" which was used in each module and about the term "TBLT". All three teachers said that they were not aware of the presence of tasks in the textbook as distinct from other activities, and so saw no differences between this book and other commercial textbooks.

I did not reckon that the book integrates task-based elements as they [the book writers] said here. I heard this term before, task-based language teaching, but do not know much about it. (Lan-SSI1)

If you did not tell me, then I would not know that. I simply think that this book is like the other commercial textbook, like New Headway, or New English Files. This is because I did not care much about the names of different teaching approaches. I just teach my students in a way I personally think is good for them. (Huong-SSI1).

Thus, not surprisingly, when asked what they understood by language learning tasks, answers by Lan and Minh show that they had little understanding of tasks (Ellis, 2018).

I always think all pieces of work that the students are required to complete are tasks (laugh). (Lan-SSI1)

I think that tasks should be something big, something important like role play or assignment. (Minh-SSI1)

On the other hand, Huong provided a more accurate definition by highlighting some key features of a task such as "interact with each other" or "exchange information".

To me, the tasks are activities designed to encourage learners to interact with each other, to improve their speaking skill. I remember that in the textbook, there are many speaking tasks in which the students have to exchange information with each other. (Huong-SSI1) 
However, Huong associated TBLT only with spoken communicative activities, which is a widespread but rather narrow view of TBLT (Erlam \& Ellis, 2018). Next, when asked to identify differences between the tasks and other activities in the textbook, all three teachers viewed the tasks not as opportunities for genuine communication in English, but as "drill practice" focused on target linguistic forms. For example, Minh said:

I think that the tasks are of no difference with the other exercises which aim to provide students with opportunities to practice certain language and structures (Minh- SSI1)

When asked how they valued the communicative tasks in the lessons, the teachers saw the tasks as optional and a much lower priority than grammar learning. For example, Lan stated that she paid little attention to the tasks in the textbook and sometimes skipped them altogether.

To be honest, I thought these activities were good and interesting. However, I did not always implement all tasks because I thought they were not so important to my students if they were not taught grammar and vocabulary in advance. (Lan)

Similarly, although Huong and Minh saw value in the communication tasks, their priority was to explicitly teach students linguistic forms.

These tasks are good for the students to communicate in the classroom but before that, they need to have "something" to say. So, it is important for them to be taught some knowledge first, then they will practice what they learnt through the tasks. However, I did not follow all of the sequences in the task section, I made some adjustments to fit my situation. (Huong-SSI1)

To do the tasks, first of all, the students should be taught relevant language then they will do the tasks to practice such language and to remember it more. (MinhSSI1)

As Van den Branden (2016) argues, the implementation of TBLT only moves forward if teachers are convinced that the approach is beneficial for their learners. For the teachers in the current study, their strong commitment to teaching vocabulary and linguistic structures to low proficiency students overrides the affordances in the textbook to teach in ways that are more congruent with TBLT.

In summary, the teachers strongly believed that their main job was to teach grammar and ensure that students did lots of form-focused practice exercises. They liked the look of the tasks in the textbook but said they rarely had time for them, and that tasks were not suitable for low proficiency learners, especially those with low motivation. Underlying these beliefs was a limited understanding of TBLT and little awareness that the design of their textbook drew, to some extent, on principles of TBLT. 


\section{Implications}

The first implication concerns the analytic tools available for researchers to analyze textbooks from a task-based perspective. Our analysis of the textbook New Cutting Edge, Elementary drew on two frameworks for understanding activities from a task-based perspective, one proposed by Littlewood (2004), and the other by Ellis (2018). As discussed earlier and reported in other studies (Butler, 2019; Erlam, 2016), both frameworks present challenges when used for coding classroom activities. Littlewood's framework defines "communicative" in terms of "functional and social interaction" (Littlewood, 1981), so undervalues input-based tasks. Ellis's (2018) four task criteria are useful for establishing a broad concept of what a task is but required some adaptation to address the vagueness in criteria 1 and 3 (a primary focus on meaning and students' own resources). An innovation in the current study was the use of both frameworks to analyze the same data in order to compare and contrast the constructs of communicativeness and task-likeness. This leads to a second implication. Given the likely difficulty many teachers have in distinguishing TBLT from CLT, the textbook analysis in the current study provides valuable evidence for the ways in which these approaches are distinct.

A third implication concerns the limited role of textbooks in shaping teachers' practice of TBLT. The current study investigated whether a textbook with a communicative orientation and containing many task-like activities and tasks could move teachers away from a traditional teaching approach focused on grammar and towards teaching with tasks. However, in their teaching, all three teachers independently stripped out most tasks and meaningful communicative activities and provided very few opportunities for interaction. In fact, they strengthened the PPP features of the textbook, a choice that most likely reflects the teachers' apprenticeship of observation (Lortie \& Clement, 1975) and their strong belief in grammar teaching. As Ellis (2018) explains, teachers understandably practice the approach they are familiar with and are likely to reject textbooks that adopt a different approach.

This raises the question of what can be done to ensure greater impact of a textbook that offers some affordances for task-based teaching in a context where TBLT is not well established or understood. In this case, a strength of the textbook New Cutting Edge, Elementary is that many of the activities are meaning-focused, and tasks are relatively frequent, despite the PPP sequencing of activities. Thus, Willis (2006) points out that while this textbook does not follow a TBLT lesson sequence, with "a little tweaking", teachers could turn the task-like activities in it into tasks and rearrange the order of activities to deliver a TBLT lesson. Harris (2016) makes a similar point. Studies by McDonough and Chaikitmongkol (2007) and Zhu and Shu (2017) are also instructive in this regard. They show that task-based materials need to be accompanied by expert guidance and ongoing support for the innovation. In a broader sense, teacher education is a critical factor in successful use of TBLT (East, 2012; Pica, 2012; Van den Branden, 2009a). Teacher education research has shown that teacher professional development needs to be participative, collaborative, and sensitive to local contexts if it is to lead to transformational educational practice (Fraser et al., 2007; Kennedy, 2011). For example, previous TBLT studies show that teachers more successfully adopt TBLT when they participate in designing tasks, observing peers and reflecting on their practice (e.g., Calvert \& Sheen, 2014; Jurateerapan, 2020; Khan, 2018; Ruso, 2007; Zhu, 2020). 


\section{Conclusion}

In conclusion, this study contributes to a growing body of research examining how language teachers engage with tasks in their classroom practice. Such studies seek to understand TBLT in relation to the complex world of the classroom, including resources and materials, environmental constraints, teacher beliefs, learner preferences and traditional expectations of teaching and learning. The current study focused on the role of the textbook as one dimension of this complexity. The findings pivot around the affordances for task-based teaching in a commercially published textbook and the ways that three teachers interpreted and implemented the textbook. The findings from the study highlight how teachers are drawn to the features of a textbook that conform to their beliefs and classroom experience but resist and may even not notice innovative features that do not. As discussed above, this has important implications for how textbooks are designed and for the professional support and teacher development that needs to accompany the introduction of a textbook if it is to successfully achieve its intended purpose.

Correspondence should be addressed to Hao Dao

Email: haodtt2014@gmail.com

\section{References}

Adams, R., \& Newton, J. (2009). TBLT in Asia: Constraints and opportunities. Asian Journal of English Language Teaching, 19(1), 1-17.

Borg, M. (2004). The apprenticeship of observation. ELT Journal, 58(3), 274-276. https://doi.org/10.1093/elt/58.3.274

Borg, S. (2013). Teacher research in language teaching: A critical analysis. Cambridge University Press.

Butler, Y. G. (2011). The implementation of communicative and task-based language teaching in the Asia-pacific region. Annual Review of Applied Linguistics, 31, 3657. https://doi.org/10.1017/S0267190511000122

Butler, Y. G. (2015). Task-based assessment for young learners: The role of teachers in changing cultures. In M. Thomas \& H. Reinders (Eds.), Contemporary task-based language teaching in Asia (pp. 348-365). Bloomsbury.

Butler, Y. G. (2017). Communicative and task-based language teaching in the Asia-Pacific region. In N. Van Deusen-Scholl \& S. May (Eds.), Second and foreign language education: Encyclopedia of language and education (3rd ed.) (pp. 327-338). Springer.

Butler, Y. G., Kang, K. I., Kim, H., \& Liu, Y. (2018). “Tasks” appearing in primary school textbooks. ELT Journal, 72(3), 285-295. https://doi.org/10.1093/elt/ccx056

Calvert, M., \& Sheen, Y. (2015). Task-based language learning and teaching: An actionresearch study. Language Teaching Research, 19(2), 226-244. https://doi.org/10.1177/1362168814547037 
Carless. (2007). The suitability of task-based approaches for secondary schools:

Perspectives from Hong Kong. System, 35(4), 595-608.

https://doi.org/10.1016/j.system.2007.09.003

Carless, D. (2009). Revisiting the TBLT versus PPP debate: Voices from Hong Kong. Asian Journal of English Language Teaching, 19, 49-66.

Carless, D. (2012). TBLT in EFL settings: Looking back and moving forward. In A. Shehadeh \& C. Coombe (Eds.), Task-based language teaching in foreign language contexts (pp. 345-358). John Benjamins.

Chan, J. (2019). Four decades of ELT development in Hong Kong: Impact of global theories on the changing curricula and textbooks. Language Teaching Research, 125. https://doi.org/10.1177/1362168819865563

Chen, Q., \& Wright, C. (2017). Contextualization and authenticity in TBLT: Voices from Chinese classrooms. Language Teaching Research, 21(4), 517-538. https://doi.org/10.1177/1362168816639985

Cunningham, S., Moor, P., Carr, J. C., Eales, F., \& Barker, H. (2005). New Cutting Edge: Teacher's resource book. Longman.

Deng, C., \& Carless, D. (2009). The communicativeness of activities in a task-based innovation in Guangdong, China. Asian Journal of English Language Teaching, 19, 113-134.

Do, C. M. T., \& Le, C. V. (2012). Teacher preparation for primary school English education: A case of Vietnam. In B. Spolsky \& Y. Moon (Eds.), Primary school English Language Education in Asia: From Policy to Practice. (pp. 106-128). Routledge.

East, M. (2012). Task-based language teaching from the teachers' perspective: Insights from New Zealand (Vol. 3). John Benjamins.

East, M. (2017). Task-based teaching and learning: Pedagogical implications. Second and Foreign Language Education, 2, 85-95. https://doi.org/10.1007/978-3-319-022468-8

Ellis, R., \& Shintani, N. (2014). Exploring language pedagogy through second language acquisition research. Routledge. https://doi.org/10.4324/9780203796580

Ellis, R. (2015). Epilogue. In T. Reinders (Ed.), Contemporary task-based language teaching in Asia (pp. 381-384). Bloomsbury.

Ellis, R. (2018). Reflections on task-based language teaching. Multilingual Matters.

Erlam, R. (2016). "I'm still not sure what a task is": Teachers designing language tasks. Language Teaching Research, 20(3), 279-299. https://doi.org/10.1177/1362168814566087

Erlam, R., \& Ellis, R. (2018). Task-based language teaching for beginner-level learners of L2 French: An exploratory study. Canadian Modern Language Review, 74(1), 126. https://doi.org/10.3138/cmlr.3831 
Farias, F, P., \& D'Elly, F, S, C, R. (2020). Task design and implementation for beginninglevel elementary school learners in South Brazil: Challenges and possibilities. In Lambert, C. \& Oliver, R. (Eds.), Using tasks in second language teaching: Practice in diverse contexts (pp. 163-178). Multilingual Matters.

Fraser, C., A. Kennedy, L. Reid, \& S. McKinney. 2007. Teachers' continuing professional development: Contested concepts, understandings and models. Journal of Inservice Education, 33(2), 153-69. https://doi.org/10.1080/13674580701292913

Harris, J. (2016). Adapting Commercial EFL Textbooks for the TBLT Classroom in Asia. 生駒経済論叢, 14(1), 1-21.

$\mathrm{Hu}, \mathrm{R}$. (2013). Task-based language teaching: Responses from Chinese teachers of English. TESL-EJ, 16(4), 1-21.

Hutchinson, T., \& Torres, E. (1994). The textbook as agent of change. ELT Journal, 48(4), 315-328. https://doi.org/10.1093/elt/48.4.315

Jaruteerapan, P. (2020). The emerging understandings and practices of task-based language teaching (TBLT) by Thai EFL student teachers. (Unpublished doctoral dissertation). Victoria University of Wellington, New Zealand.

Kennedy, A. (2011). Collaborative continuing professional development (CPD) for teachers in Scotland: aspirations, opportunities and barriers. European Journal of Teacher Education, 34(1), 25-41. https://doi.org/10.1080/02619768.2010.534980

Kiely, R \& Askham, J. (2012). Furnished imagination: The impact of pre-service teacher training on early career work in TESOL. TESOL Quarterly, 46(3), 496-518. https://doi.org/10.1002/tesq.39

Lai, C. (2015). Task-based language teaching in the Asian context: Where are we now and where are we going? In M. Thomas \& H. Reinders (Eds.), Contemporary taskbased language teaching in Asia (pp. 12-29). Bloomsbury.

Le, V.C. (2011). Form-focused instruction: A case study of Vietnamese teachers' beliefs and practices (Doctoral degree), The University of Waikato.

Le, \& Barnard, R. (2009). Curricular innovation behind closed classroom doors: A Vietnamese case study. Prospect, 24(2), 20-33.

Lightbown, P., \& Spada, N. M. (2006). How languages are learned. Oxford University Press.

Littlewood, W. (2004). The task-based approach: Some questions and suggestions. ELT Journal, 58(4), 319-326. https://doi.org/10.1093/elt/58.4.319

Littlewood, W. (2015). Introduction- Part one in T. Reinders (Ed.), Contemporary TaskBased Language Teaching in Asia. Bloombury Publishing. https://wwwbloomsburycollections-com.login.ezproxy.library.ualberta.ca/book/contemporarytask-based-language-teaching-in-asia-contemporary-studies-in-linguistics/ch21task-based-assessment-for-young-learners-the-role-of-teachers-in-changingcultures 
Long, M. H. (1996). The role of the linguistic environment in second language acquisition. In W. C. Ritchie, \& T. K. Bhatia (Eds.), Handbook of second language acquisition (pp. 413-468). Academic Press.

Long, M. H. (2015). Second language acquisition and task-based language teaching. John Wiley \& Sons.

Lortie, D. C., \& Clement, D. (1975). Schoolteacher: A sociological study. University of Chicago Press.

Luo, S., \& Xing, J. (2015). Teachers' perceived difficulty in implementing TBLT in China. In M. Thomas \& H. Reinders (Eds.), Contemporary task-based language teaching in Asia (pp. 139-155). Bloomsbury Publishing.

MOET. (2008b). Đề án Ngoại ngữ Quốc gia 2020 [Vietnam’s national foreign language project 2020]. Hanoi, Vietnam: MOET.

McDonough, K., \& Chaikitmongkol, W. (2007). Teachers' and learners' reactions to a task-based EFL course in Thailand. TESOL Quarterly, 41(1), 107-132. https://doi.org/10.1002/j.1545-7249.2007.tb00042.x

Newton, J. (2021). The adoption of TBLT in diverse contexts: Challenges and opportunities. In M. H. Long \& M. Ahmadian (Eds.), Cambridge handbook of taskbased language teaching. Cambridge University Press.

https://www.cambridge.org/core/books/cambridge-handbook-of-taskbased-languageteaching/AFDAFDC20AC73DF86ABEB1DA70BBC155

Newton, J., \& Bui, T. (2017). Teaching with tasks in primary school EFL classrooms in

Vietnam. Recent perspectives on task-based language learning and teaching, 27, 259.

Nguyen, B., Crabbe, D., \& Newton, J. (2018). Teacher transformation of oral textbook tasks in Vietnamese EFL high school classrooms. TBLT as a researched pedagogy. Amsterdam: John Benjamins.

Nguyen, G. V. (2013). Orienting to pedagogical innovation: A case study of Vietnamese teachers' beliefs and practices regarding task-based language teaching. (Unpublished doctoral dissertation). University of Waikato, New Zealand.

Nguyen, G. V., Le, V. C., \& Barnard, R. (2015). "Old wine in new Bottles": Two case studies of task-based language teaching in Vietnam. In M. Thomas \& H. Reinders (Eds.), Contemporary task-based language teaching in Asia (pp. 68- 86). Bloomsbury Publishing.

Nguyen, T. A., Jaspaert, K. \& Van den Branden, K. (2018). EFL teachers' perceptions of task-based language teaching in a Vietnamese university. The European Journal of Applied Linguistics and TEFL, 7 (1), 73-90.

Nguyen, \& Franken, M. (2010). Conceptions of language input in second language acquisition: A case of Vietnamese EFL teachers. Language Education in Asia, 1(1), 62-76. https://doi.org/10.5746/LEiA/10/V1/A06/Nguyen_Franken

Ogilvie, G., \& Dunn, W. (2010). Taking teacher education to task: Exploring the role of teacher education in promoting the utilization of task-based language teaching. 
Language Teaching Research, 14(2), 161-181.

https://doi.org/10.1177/1362168809353875

Oliver, R., \& Bogachenko, T. (2018). Teacher perceptions and use of tasks in school ESL classrooms. In K. Van den Branden., V. Samuda, \& M. Bygate (Eds.), TBLT as researched pedagogy (pp. 72-95). John Benjamins.

Pica, T. (2012). Foreword. In A. Shehadeh \& C. A. Coombe, Task-based language teaching in foreign language contexts: Research and Implementation (pp. $\mathrm{xv}-\mathrm{xix})$. John Benjamins.

Ruso, N. (2007). The Influence of task-based learning on EFL classrooms. Asian EFL Journal, 18, 1-23.

Shintani, N. (2016). Input-based tasks in foreign language instruction for young learners (Vol. 9): John Benjamins.

Thomas, M., \& Reinders, H. (2015). Contemporary task-based language teaching in Asia. Bloomsbury Publishing.

Tomlinson, B. (Ed.). (2003). Developing materials for language teaching. Continuum.

Tran, G. N. (2015). Investigating teachers' implementation of the task-based curriculum from a teacher cognition perspective: A case study of a Vietnamese uppersecondary school. (Unpublished doctoral dissertation). University of Wollongong, Australia.

Van den Branden, K. (Ed.). (2006). Task-based language education: From theory to practice. Cambridge University Press. https://doi.org/10.1017/CBO9780511667282

Van den Branden, K. (2009a). Diffusion and implementation of innovations. In M. Long \& C. Doughty, The handbook of language teaching (pp. 659-672). Wiley Blackwell.

Van den Branden, K. (2016). Task-based language teaching. In G. Hall (Ed.), The Routledge handbook of English language teaching (pp. 238-250). Routledge.

Van Den Branden, Van Gorp, K., \& Verhelst, M. (Eds.), Tasks in action: Task-based language education from a classroom-based perspective. (pp. 32-63). Cambridge Scholars Publishing.

Vandommele, G., Van den Branden, K., \& Van Gorp, K. (2018). Task-based language teaching: How task-based is it really? In Samuda, V., Van Den Branden, K., Bygate, M., Reflections on task-based language teaching (pp. 165-198). John Benjamins.

Zhang, Y. (2015). Task-based language teaching in the primary schools of South China. In M. Thomas \& H. Reinders (Eds.), Contemporary task-based language teaching in Asia (pp. 87-101). Bloomsbury.

Zhang, Y., \& Luo, S. (2018). Teachers' beliefs and practices of task-based language teaching in Chinese as a second language classrooms. Chinese Journal of Applied Linguistics, 41(3), 264-287. https://doi.org/10.1515/cjal-2018-0022 
Zheng, X., \& Borg, S. (2014). Task-based learning and teaching in China: Secondary school teachers' beliefs and practices. Language Teaching Research, 18(2), 205221. https://doi.org/10.1177/1362168813505941

Zhu, Y., \& Shu, D. (2017). The Haitong Project: Exploring a collaborative approach to implement TBLT in primary classrooms in China. Language Teaching, 50(4), 579585. https://doi.org/10.1017/S0261444817000180

Zhu, Y. (2020). Implementing tasks in young learners' language classrooms: A collaborative teacher education initiative through task evaluation. Language Teaching Research, 00 (0), 1-22. https://doi.org/10.1177/1362168819894706 


\section{Appendix}

\section{Interview Questions for Teachers}

1. There are a section called "task" in each module in the textbook. So how do you understand about this term?

2. Did you notice any difference between these tasks with other activities?

3. Did you have challenges of implementing these tasks?

4. Have you ever heard about the terms task-based language teaching? How do you understand about this term?

5. What is your view about the approach that focused students on meaningful communication? Do you think it is feasible for your students?

6. Have you ever attended any special workshop or training course about TBLT before? If yes, can you specify? 